\title{
The Reuse of Texts in Indian Philosophy: Introduction
}

\author{
Elisa Freschi
}

Published online: 31 October 2014

(C) The Author(s) 2014. This article is published with open access at Springerlink.com

\begin{abstract}
The study of textual reuse is of fundamental importance in reconstructing lost or partially lost texts, passages of which can be partly recovered through other texts in which they have been embedded. Furthermore, the study of textual reuse also provides one with a deeper understanding of the modalities of the production of texts out of previous textual materials. Finally, it constitutes a unique chance to reconsider the historicity of concepts such as "author", "originality" and "plagiarism", which do not denote really existing universals, but have rather evolved-and still evolve-in different ways in different cultural milieus. After a general introduction and an analysis of the historical background of textual reuse in India and Europe, the essay attempts some general conclusions regarding the formulas introducing instances of textual reuse in Classical South Asian texts.
\end{abstract}

Keywords Originality · Indian Philosophy · Textual reuse · Quotations · Plagiarism · Interlanguage

The shrewds like imitating the others and pretend that the new and the modern things are their inventions. Instead, you have to imitate the men of the past by studying the written documentation. It is by refining the art of emulation during all one's life that one becomes wise.

(Itakura Shigenori's will for his son)

E. Freschi $(\bowtie)$

Institute for the Cultural and Intellectual History of Asia, Austrian Academy of Sciences, Vienna, Austria

e-mail: elisa.freschi@oeaw.ac.at 


\section{Why do We Need a Study of Textual Reuse at All?}

(1) Textual-critical reasons:

- In order to restore lost or partially lost texts. ${ }^{1}$

- In order to achieve better text editions (e.g., one needs to know whether a quotation embedded in a later text is a reliable witness- this also depends on the general attitude towards the kind of text quoted). ${ }^{2}$

\section{(2) Historical-critical reasons:}

- In order to gain a better understanding of Indian texts and/within their history (e.g., does the lack of reuse of passages by a certain author in later texts mean that $\mathrm{s} /$ he was not influential?). ${ }^{3}$

- In order to better evaluate the relation of Indian authors to other authors (e.g., whom did they quote more frequently? did they feel like naming revered teachers, or did they name only adversaries?).

- In order to better understand Indian habits of reading and writing/ composing texts (e.g., did Indian authors quote even longer passages literally? did they quote ad sensum? did they have a small library of texts behind their desk?).

\footnotetext{
${ }^{1}$ Ernst Steinkellner, in his pioneer study on the topic of quotations (see infra, section 3.1), writes: "It will be through careful observation of the many kinds of minute relations between the extant textual materials that we shall gradually gain some knowledge of the actual process and conditions of the production of these materials. What purpose does this serve? Beyond its cultural import, its main value is for our philological work. For it is only if we are able to see how the texts were transmitted and produced and, specially, which texts were used in producing new ones, that we can base our argument for the constitution of texts on firm ground and narrow the range for philological and interpretational arbitrariness. If we can determine for example that a certain text has been found useful and has, therefore, been referred to, expressedly quoted or silently copied, or has been excerpted or plagiarised, and that parts of its textual material, i.e. larger textual units, sentences, phrases, words, or-exceptionally-even of its conceptual materials, have been transmitted to the texts of others by these various processes, these later texts can then be considered as highly valuable witnesses for a decision on the reality of their source, should its original be lost" (Steinkellner 1988, p. 105). See also, on reused texts found in commentaries, Preisendanz (2008, pp. 611-612).

2 "But even if it [=the original] is not lost, these derivative textual finds signify an important supplementation of the extant manuscript-remains. For in view of the fact that one or more possibly extant codices of a particular original Sanskrit text will originate normally from the last period of Indian Buddhism—sometimes even as copied under conditions of flight or exile-quotations and other textual elements derived from it and to be found in other texts whose codices come from the same time must be considered as most valuable witnesses for the text of the archetype. In many cases these quotations etc. are the only places where variant readings can be found" (Steinkellner 1988, pp. 105-106). See also, on reused texts found in commentaries, Preisendanz (2008, p. 611).

${ }^{3}$ On the same subject, but from the standpoint of Western Ancient and Medieval authors, Ch. Schulze denies the direct link between number of instances of reuse and the fate of a text: "Fehlende Zitate bei späteren Schriftstellern können mannigfaltige Ursachen haben-früher Textverlust, Überstrahlung durch spätere Autoritäten, Unpassendes für den eigenen Gedankengang (z.B. weil man einer anderen Schultradition anhängt als der Vorgänger) usw.-und müssen keineswegs einer Abwertung des Autors und seiner Professionalität entspringen" (Schulze 2004, p. 21). A less drastic verdict is that of Büchler et al. (2013), where interesting statistical depictions of literal reuses are produced and a difference in the literality of reuse among genres is noted.
} 
- In order to better understand the targeted Indian readership or audience (e.g., was acquaintance with older texts presupposed? was this a precondition of understanding a later text?). ${ }^{4}$

(3) In order to re-frame our historically conditioned notions of "text", "author", "originality", "copyright" and so on.

\section{State of the Art}

The study of textual reuse is a largely unexplored field within Indian saastric literature. Apart from a special issue of Religions of South Asia (initiated by a paper of mine (Freschi 2012) and brilliantly edited by J. Suthren Hirst), one has to gather references to this topic in different journals and books, mostly within articles or volumes dedicated to different themes (for instance, in the articles of Petra KiefferPülz).

For Steinkellner's pioneering study, see section 3.1. Like Steinkellner, although with a different focus, Ernst Prets' project on Fragments of Indian Philosophy (about which see http://nyaya.oeaw.ac.at/cgi-bin/index.pl), the ensued conference (see http://nyaya.oeaw.ac.at/cgi-bin/conf/adv.pl) and its forthcoming proceedings focus on the content of the collected fragments rather than on the form of quoting, and, thus, more on point No. 1 above than on points No. 2 and 3 .

Noteworthy is also the volume Re-Use in Art and Politics (Hegewald and Mitra 2012), which focuses on examples of recycled elements in politics and in the history of art, and more specifically on the political significance of artistic reuses (from the cult of Jagannātha and the sacred artefacts related to it, which have been recycled as part of a specific political agenda of "tribalization" to the many reuses of the image of "Mother India", in different political contexts).

Outside the Indian context, much research has been done on the topic of intertextuality and citations. Within this volume, some bibliographical suggestions about it can be found in the reference list at the end of the present introduction, and in Graheli's article. Further indications can be found in Trikha's contribution to the workshop organised by the present research-project and available here: http:/asiatica. wikispaces.com/quotations+and+re-use+of+texts+in+Sanskrit+texts) and in the bibliography of Trikha $2012 .^{5}$

\section{Forms of Reuse}

Broadly, one can point to two possible ways of distinguishing among reuses of former material:

\footnotetext{
${ }^{4}$ For the Tibetan version of these historical-critical reasons, see Hugon's contribution to the present volume.

${ }^{5}$ On the relation of the study of intertextuality and that of textual reuse see also Freschi and Maas forthcoming $b$.
} 
(1) From the point of view of the literality of the reused textual material:

- Quotations (the content is the same, the form may be slightly modified).

- References (only the content is the same).

- Interlanguage (ideas which are broadly common at a certain time and cannot be traced back to a certain author).

(2) From the point of view of the explicitness of the reuse:

- Passages acknowledged as having been authored by someone else.

- Passages silently embedded in one's own text.

I derive the idea of an "interlanguage" from María de las Nieves Muñiz' discussion of an interlingua available to Renaissance to Neoclassical authors in Europe. ${ }^{6}$ This scholar argues that one cannot always settle whether, e.g., Giacomo Leopardi directly read the author whose ideas he refers to. The same ideas might have well been part of a shared background of commonly agreed notions (for an Indian application of this concept, see Vergiani's contribution, section 2.3.2). Such an interlanguage, I might add, can also include textual passages whose author(s) is no longer determined, which can be compared to the situation with Western proverbs or antonomasia uses. At the topmost limit of it are collocated laukikanyāyas, stock examples of peculiar cases. The issue of interlanguage has to be held in mind when dating a text on the basis of what one deems to be "unacknowledged quotations", which may end up being nothing but instances of interlanguage. An interesting example is that of the "quotations" from the Káasikā $V r t t i$, which might only be an evidence in favour of a shared approach to grammar (see Vergiani's contribution) and which should, thus, be used only with extreme caution (see, e.g., Wezler and Motegi's datation of the Yuktidipika on the basis of a single "quotation" of the Kásíika Vrtti in their edition of the former text, Wezler and Motegi 1998).

A more detailed classification can be found in the contributions by Doctor and by Hugon, who connects the above elements in a unitary scheme, and in Trikha 2012, who takes into account the evaluation of the reused text in the one re-using it. In fact, since many embedded texts may again embed older texts, the presence of, e.g., a positive evaluation of a Buddhist author in a Jaina text may be evidence for the fact that the sentence is part of a larger passage extracted from a Buddhist source (see Trikha 2012, p. 153 for a similar case in the Jaina Vidyānandin's Satyaśāsanaparīkșā). Graheli's contribution in this collection also throws more light on the role of the author's evaluation of the passages he reuses, with a specific stress on the epistemological side of this topic.

\subsection{Classification of Reuse}

The main differences in the attempts to classify the various cases of textual reuse depend on the purpose one aims at. The first systematic attempt to classify them is

\footnotetext{
${ }^{6}$ María de las Nieves Muñiz, "Citazioni implicite e letture illuministe nello Zibaldone", international workshop Con voce d'altri: scrittura, riflessione, citazione, organized by the Leopardi Centre, University of Birmingham, in Rome, Sapienza University, 21st May 2010.
} 
Ernst Steinkellner's one (Steinkellner 1988). Steinkellner principally aimed at reconstructing the texts of Buddhist epistemological authors through other testimonies and not-as is also in our purpose-at analysing the history of a determinate tradition through the angle of textual reuse. Thus, Steinkellner aimed at the evaluation of the witnesses and of their relation to the text to be reconstructed, which he called $\mathrm{T}$.

In his pioneer essay and in the work of the scholars following it, ${ }^{7}$ one finds:

- Ce citatum ex alio, literal quotation of a text in T

- Cee citatum ex alio modo edendi, quotations with minor differences from the text quoted

- Ce' citatum ex alio usus secondarii, reused passages embedded in a later text without any acknowledgement of their being of foreign origin

- Ce'e citatum ex alio usus secondarii modo edendi

- Ci citatum in alio, literal quotation of $\mathrm{T}$ in a later text

- $\operatorname{Re}$ citatum ex alio modo referendi, where only the content of a certain text is reported in the text one is editing

- P textus parallelus, a text by the same author literally reproducing portions of T.

- P' textus parallelus usus secondarii

- PV textus parallelus variatus, a text by the same author reproducing por-tions of $\mathrm{T}$ with variations

- PV'textus parallelus variatus usus secondarii

The distinction between Ce and Cee is arbitrary, at least to some extent, since we do not know which version of a certain text the author under examination had studied, nor is the manuscript tradition always reliable as for small differences.

In fact, I am indebted to Helmut Krasser for making me aware of the difficulty in judging the reliability of literal quotations. Due to the paucity of manuscripts and of reliable critical editions, one is often confronted with ambiguous cases. For instance, a divergence between a text of Dharmakirti and the same text quoted in Dharmottara may lead to the following options: (1) Dharmakīti has been inexactly quoted by Dharmottara, or (2) Dharmottara's text with Dharmakīrti's quotation has been poorly transmitted or edited, or (3) Dharmottara was quoting literally, but Dharmakīrti's text has been poorly transmitted or edited. A similar case is discussed in Pellegrini's contribution, section II.2.3. ${ }^{8}$

Steinkellner's original system and his modifications until 2009 did not examine separately the case of reused texts which had been embedded in a later text which was itself quoted or reused by the text one is currently reading (e.g., a quote of the Nyāyasūtra within a passage of the Nyāyabhāşya quoted by a later Naiyāyika). This lack did not represent a flaw for Steinkellner's purposes, since one would not trust

\footnotetext{
7 For this and the following abbreviations, see Steinkellner (1988), Lasic (2000b, pp. 25-26), Kellner (2007, pp. 38-39), Trikha (2012, pp. 130-140).

8 An awareness of this problem is highlighted also in Lasic' introduction to his Vyāpticarcā edition, on Ce/Cee: "Tatsächlich sagt die Charakterisierug modo edendi oft nicht mehr aus, als daß die zitierte Passage eine abweichende Form demgegenüber hat, was uns beispielsweise aus den Editionen des zitierten Textes bekannt ist. Dabei kann nicht mit Sicherheit ausgeschlossen werden, daß Jñānaśrimitra eine andere Version des zitierten Textes vorlag" (Lasic 2000b, p. 25).
} 
much these third-hand reuses while preparing the critical edition of a given text, whereas scholars more exactly focusing on the analysis of textual reuse for its own sake could prefer a specific notation.

In accordance to this need, Trikha has introduced the following symbols:

- $\langle\mathrm{Ce}\rangle \mathrm{Ce}$ embedded in a larger reused text within $\mathrm{T}$

- $\langle$ Cee $\rangle$ Cee embedded in a larger reused text within $\mathrm{T}$

- $\langle\mathrm{Ci}\rangle$ literal quotation of $\mathrm{T}$ embedded in a larger reused text

- $\langle\mathrm{Re}\rangle \mathrm{Re}$ embedded in a larger reused text

Steinkellner had hypothetically ${ }^{9}$ suggested to add to the usus secondarii also an usus tertiarii symbolised with Ce" (or P") and defined as a Ce' (or P') text "secondarily used by yet another author". This category could overlap with the $\langle\mathrm{Ce}\rangle$ one, but the steps might be more than three and their number could be difficult to be calculated. In such cases, Trikha's symbols can be used without fear of being trapped in a too complicated genetic hypothesis. Else, one might wish to follow Lasic' introduction of a precise number showing the degree of reuse: $\mathrm{Ce}(1), \mathrm{Ce}(2)$, etc. (with the corresponding $\mathrm{Ce}(1)$ e, etc.) (Lasic 2000a, p. 27).

At this point one might ask whether it is not more convenient to just drop entirely Steinkellner's terminology and just use a description of the similarities between the re-using text and the reused one. Krasser (see the $\mathrm{PhD}$ thesis he supervised: Mac Allister 2011, p. 11) and Trikha (2012, p. 133) suggest the following symbols:

- $=$ in case of exact correspondence

- $\sim$ in case of loose correspondence

- \# in case of correspondence only in content ${ }^{10}$

These symbols have the advantage of avoiding any evaluation of the material and any genetic hypothesis concerning the situation one is confronted with. This sheer description has, in turn, the advantage of non-conditioning the reader with the editor's judgement about the text's history. For instance, an exact correspondence may be the result of the processes labelled in Steinkellner's terminology as $\mathrm{Ci}$ or $\mathrm{Ce}$ (or Ce'), but also of endless intermediate steps of exact reproduction of the same passage.

The same reasons, may, however, be used in favour of Steinkellner's classification, which in many cases enables the reader to better understand the textual history of a given passage (or, at least, to see a plausible reconstruction of it).

Thus, in my contribution (see Freschi infra) I have kept using Steinkellner's terminology hoping to be in this way able to deliver some additional information and, more importantly, to make readers aware of my reconstruction hypothesis. I would nonetheless strongly discourage the use of Steinkellner's symbols in the case of more complex textual histories, for instance in the case of religious texts where the direction of borrowing is far less clear (see infra, Dębicka-Borek's discussion of the Pāñcarātra case).

\footnotetext{
9 "This kind of text [Ce"] as well as no. 10 below [P"] is only differentiated to show further possibilities of this system. I have, however, no examples for these at the moment" (Steinkellner 1998, p. 117).

10 Trikha 2012 uses these and Steinkellner's symbols side by side.
} 


\subsection{Marks of Reuse}

The lack of literature I mentioned above is even more acute in regard to the technical aspect of textual reuse in Indian philosophical texts. I can only mention Emery R. Boose's paragraphs on iti, āha and related verba dicendi and adverbs in Tubb and Boose (2007). The book is great in concept, but it is still very basic in its indications (at least in this case).

However, in order to be better analysed, the issues sketched above need a thorough investigation in Indian texts, which should keep in sight their historical development within an absolute chronology and a chronology of the development of each philosophical school.

When I started working on this project, I asked myself and the other contributors to pay attention to the following points:

(1) Whether there is the feeling of the need for literal quotations at all.

(2) Whether literal quotations are explicitly marked (at least as a rule) by, e.g., ity uktam or similar expressions.

(3) Whether references are marked (at least more often than not) by, e.g., iti manyate or similar expressions.

(4) Whether literal quotations are more often than non-literal ones marked as such (at least by iti) and, if so, whether their source is also mentioned.

(5) Which kinds of texts are literally quoted (sacred texts? texts by revered teachers? adversaries' texts? texts the readership is expected to know and would hence be disturbed to find changed? texts the readership is not expected to know and hence needs to be acquainted with?)?

(6) Are iti śruti, iti smrti, iti prasiddha, iti dṛșta, ity āmnāta and similar indications reliable?

The more technical side of these questions (that is, frequency and number of quotations and their marks) will be better answered through an even greater amount of case studies in as far as possible different fields of Indian philosophy. In this sense, I hope that the present study will initiate a new way of looking at texts and a deeper awareness of the mechanisms of reuse within them. Similarly, forthcoming studies inspired by this approach and preferably based on manuscript sources, (see above, section 3.1 for a caveat about working only on editions) might be able to draw conclusions out of the raw data provided by the next contributions. For instance, I suspect that traditions more closely linked to writing might have developed different habits from ones still 'suspicious' about the written form of a text. However, this prejudice is in need for confirmation. ${ }^{11}$

A preliminary study such as the present one, may still throw some light on the general Indian attitude towards quotations and on the particular attitude of a certain school (e.g., Pramāṇavāda, Nāvya Nyāya, Prābhākara Mīmāṃsā, etc.) or author. I am inclined to think that some general conclusion can be drawn in this regard, since

\footnotetext{
11 Together with Catherine Cantwell and Jowita Kramer, I have indeed organised a panel at the 2014 IABS conference on reuse in the specific context of Buddhist literature. The panel (and its proceedings) will throw light on whether there are some Buddhist specificities in the ways of reusing texts.
} 
my own studies on Mīmāṃsā texts show a surprising consistency of results (see infra, Freschi, section 8), and since they do not conform, for instance, with the data derived out of Pramāṇavāda texts (at least as analysed, for instance, in Steinkellner 1988; Lasic 2000b; Kellner 2007).

\section{Intersections of Authoriality and Textual Reuse in India and in the West}

\subsection{Critical Background}

One of the main arguments in favour of the study of (geographically or historically) remote texts and cultures is the bewilderment effect one derives from it. In fact, through such comparisons (studying another culture cannot occur without aconscious or unconscious - comparison, I believe) one is forced to see how the mainstream contemporary Western concept of "copyright" and "intellectual property" is not the only possible way to deal with the topic of ideas and cultural products. In contrast, this approach depends on particular historical circumstances and has, hence, not always and everywhere been the norm.

From the time of classical Greece and Rome and possibly until the 17th century and afterwards, ${ }^{12}$ the use of copies as a homage to the original was common and widespread throughout the West and in India. Painters learnt to paint by copying and reproducing famous paintings, musicians played others' works or wrote new works using well-established structures, novelists and playwrights translated or rearranged ancient plots, from the Medea to Jesus' life, from the Troy war to St. George and the Dragon. Novus was often an abusive word in Latin, and several trends evaluating the role of novelty (as with the poetae novi) indirectly stress how opaque this evaluation seemed.

In general: the use of previous models was the rule and the way of quoting/ referring to them was relatively loose. Only with the Bible (and a few other foundational texts) did a tradition of literal quoting develop. All other sources were used rather than being reverentially (and literally) copied. Christian Schulze comments, with a dismissive bias, on the editorial work imposed on Dioskurides' Materia Medica as follows:

Zweifellos handelte es sich bei manchem Eingriff in den Dioskuridestext schlicht um Barbarei, die den Text verstümmelte. Man hatte mit diesen Abänderungen die Ehrfurcht vor dem Ursprungstext und ihrem Verfasser über Bord geworfen: Während Hippokrates für Galen oft eine sakrosante Bedeutung hatte oder-um einen anderen Bereich $\mathrm{zu}$ nennen-Origenes auf aufwendigste Weise versuchte, einen möglichen originalen Bibeltext herzustellen (um ihn erst dann $\mathrm{zu}$ kommentieren), existierten Bedenken vergleichbarer Art bei pharmazeutischen Texten nicht. Selbst der große

\footnotetext{
12 On copying in Grammars and Dictionaries until the end of the 18th century, see Tieken-Boon van Ostade (1996). Among the many cases of reuse of form and plot within contemporary fiction, see that of Kathy Acker, discussed in Cao (2012).
} 
Dioskurides war davon nicht ausgenommen (Schulze 2004, p. 31, emphasis added).

By the way, even the custom of literally quoting biblical passages does not mean that the Bible was not forced into one's agenda. On the contrary, literal quoting was often employed in order to violate the contextual meaning and to impose a new one. ${ }^{13}$

A different case is that of China, where the tradition of copying is also very ancient (and still current nowadays). In this case, however, copies were absolutely true to their original. Manuscripts were faithfully reproduced and-unlike in Indianeither emended nor improved by copyists. ${ }^{14}$

Lest it is thought that I am here understanding the switch from an "open, usable text" paradigm to a closed text paradigm as a linear and mono-directional process, the reader should remember that a philology based on historical principles was already developed in Alexandrine times and then replaced by the un-historical attitude towards texts in the Middle Ages. The suggestive incipit of Mülke's Der Autor und sein Text reminds one of these contradictory tendencies as follows:

Die Geschichte der Weltliteratur ist auch eine Geschichte der Verfälschungen. Von den Anfängen bis in die Gegenwart sind Werke gerade vielgelesener Autoren nach ihrer Veröffentlichung von fremder Hand verändert worden. Um nur einige Beispiele aus der Antike zu nennen: Die homerischen Epen las man im dritten Jahrhundert vor Christus in so entstellter Form, daß sich aus der Erkenntnis der text- und echtheitskritischen Anstöße und dem Versuch, diese systematisch zu beseitigen, die alexandrinische Philologie entwickelte. Die Texte der attischen Tragödie sind bis heute durch Störungen beeinträchtigt, die offenbar auf Eingriffe sowohl der Theaterschauspieler als auch späterer Bearbeiter zurückgehen. Die plautinischen Komödien wurden ebenso wie später die Satiren Iuvenals durch fremde Zusätze verändert. Schon die antike Kommentare bezeugen unechtes Versgut in der Aeneis Vergils. Auch die großen christlichen Dichter Iuvencus, Prudentius und Paulinus von Nola blieben davon nicht verschont. Und im vierten Jahrhundert nach Christus veranlaßte die Verwilderung des lateinischen Bibeltexts Papst Damasus und Hieronymus, eine neue, kritisches Ansprüchen genügende Übersetzung aus dem Hebräischen und Griechischen zu besorgen. ${ }^{15}$

\footnotetext{
13 For an interesting case of this extensive use of literal meaning, see Nikolsky (2010, p. 246).

14 I am grateful to Filippo Salviati for having discussed with me the Chinese case and, in particular, the way copyists of the Lanting $\mathrm{Xu}$ included even erasures etc. while copying the original manuscript. Images of the extant copies are easily available on the web. See also infra, Appendix.

15 Mülke (2008, p. 11). Mülke's text is inspiring and thought-provoking. The concluding remarks of his study acknowledge a tension between authors, who beg that their works are not "employed", emended, epitomised, etc., and the actual usage — even of these same authors as soon as others' works were at stake. Mülke also suggests we rethink the concept of authorship, since the first element of this tension proves that - against what one could think by considering only the case of India-the reason for this openness of texts was not the lack of an individual author.
} 


\subsection{Modes of Production of Texts: From the Copyist to the Plagiarist}

Instances of reuse are copious in both written and oral texts. Formulae are also a sort of "reuse", although they lack (the memory of) an author. Moreover, until the invention of print, in many places "the physical act which produced originals was the same as that which produced copies. Writers were responsible for both" (Burrow 1982 , p. 31). Hence, they were often used to both copying and actively writing, and used the first ability within the second.

Again, Burrow quotes a famous passage of St. Bonaventure (13th c.) about the modus faciendi librum ("the way of making a book"):

There are four ways of making a book. Sometimes a man writes others' words, adding nothing and changing nothing, and he is simply called a scribe [scriptor]. Sometimes a man writes others' words, putting together passages which are not his own; and he is called a compiler [compilator]. Sometimes a man writes both others' words and his own, but with the others' words in prime place and his own added only for purposes of clarification; and he is called not an author but a commentator [commentator]. Sometimes a man writes both his own words and others', but with his own in prime place and others' added only for purposes of confirmation; and he should be called an author [auctor]. ${ }^{16}$

So, no one just writes without any model: "The scheme simply does not allow for that possibility" (Burrow 1982, p. 31). Moreover, how reliable is Bonaventure's description of the scriptor? In fact, scribes did not "change nothing". On the contrary, the scribe added and changed "not only inadvertently, like the compositor, but also deliberately. He replaces obscure expressions with more familiar ones, omits and rewrites passages, and sometimes adds passages from other sources or even passages of his own composition" (Burrow 1982, pp. 31-32). At least in India, the case I am more acquainted with, a copyist may act this way in order to alter the text, but, more often, in order to improve it or to better preserve it (hence, explanations may be added whenever a passage seems too obscure to be understood). Hence, the copyist does not perceive himself/herself as someone who is violating the text, but rather as its protector. Was Bonaventure unaware of that? My own answer is that he did not perceive such editorial changes as "changes". The only changes worth mentioning were the ones made by a compiler, all others were just part of the process of copying. Nowadays, we are still used to the idea that editors working for a publisher are allowed to re-write the form of a proposed text and to re-arrange its content, and yet they are not mentioned as co-authors.

The co-existence of copying and "creative" writing within one's daily routine also applies to our most recent past: before the widespread use of photocopies, scanners, cameras, etc., one was forced to physically copy a text one was interested in. Hence, one would have thousands of sheets or notebooks with quotations, perhaps not always formally identified as such, many of which were meant to be reused in successive

\footnotetext{
16 St. Bonaventure, fourth quaestio in the Proem to his commentary on Peter Lombard's Sentences, quoted in Burrow (1982, pp. 30-31).
} 
works. A notorious instance is Giacomo Leopardi's Zibaldone, where the author copied others' texts side by side with his own notes (the whole book is now considered one of Leopardi's masterpieces). ${ }^{17}$ On the contiguity of "creative writing" and “copying" see also Del Toso's contribution within this collection, section 1.1.4 (e).

On the contrary, technical facilities enable the possibility of an exact reproduction and, hence, careless reproductions have now become the exception rather than the rule and are seen as a flaw to be censured. Similarly, the economic interests connected with the idea of a copyright (the development of a class of professional authors, the career advantages linked with the number of original publications one has authored, etc.) have heavily contributed to the custom of literal quotations and to the construct of the flaw of "copying". As explained by Ingrid Tieken-Boon van Ostade, all authors of English Grammars and Dictionaries regularly copied from the work of their predecessors and improved on it. ${ }^{18}$ It is only in the 18th century, however, that the social appreciation of this changes:

The desire to make money quickly and by any available means, including theft, seems to be important in distinguishing plagiarism from what has come to be referred to as unacknowledged copying. According to Lafollette, "Once 'authorship' began to carry the potential for profit, then plagiarism became a matter of concern to all authors and publishers" (1992, p. 14). ${ }^{19}$

Accordingly, Tieken-Boon van Ostade explains how the very word "plagiary" found its way into English in the 17th century, but gradually changed its meaning from "kidnapper" to "book stealer" (mid-18th century) (Tieken-Boon van Ostade 1996, p. 86). Presently, some author, such as Kathy Acker, have expressed their criticism of the capitalist mode of production exactly by "plagiarising" Classical texts (see Cao 2012), whereas several political parties claim that there should be "no copyright on ideas", and, consequently, on intellectual works (see Bartels 2009, especially chapter 1.1).

Will the present concept of a "closed" text always be the case? Perhaps not. Apart from the competing models (such as the Chinese one), the habit of "wikiing" also points (back) to an open-text future. Future writers may feel indifferent towards the concept of intellectual property and decide to compose future encyclopedias by just compiling existing texts. They might even decide they do not care so much for their names to be remembered and/or sign just by their first names, like many Middle Age "artists" and "authors".

\subsubsection{Forms of Production of Texts: Does Orality Play a Role?}

At first sight, one might suggest that quotations may have to do with the written form of a text. In a culture which does not know any written record, a text exists

\footnotetext{
17 I am grateful to Franco D'Intino for having discussed this instance with me.

18 About Lindley Murray she says that "Murray's main line of approach seems to have been to present the material he found in his sources in a more lucid and coherent sense", Tieken-Boon Van Ostade (1996, p. 89).

19 Tieken-Boon van Ostade (1996, p. 85). I. Tieken-Boon Van Ostande also kindly informs me that Ann Fisher, when she accused someone of having "borrowed" bits and pieces from her grammar, claimed he was "stealing the bread out of my mouth".
} 
only when, and insofar as, it is performed. This may legitimate the performer's action over the text. In other words, while performing a text which only exists in her head, one may feel natural to intervene on the text $\mathrm{s} / \mathrm{he}$ is performing, much more so than if s/he were performing a text fixed in a written form. This is not the case if the performer executes a well-known passage, e.g., of a ritual text, since in this case (part of) the audience could censure her deviations.

However, the link between orality and openness is not fix. Apart from the case of the Vedic texts, which are memorised in a way meant to preserve all their features, ${ }^{20}$ other examples show that fixedness, openness and orality and writing can be variously combined. For instance, in the case of Somali poetry, Martin Orwin explains that Somali maanso poetry knows definitive texts independently of writing and of Western influences. ${ }^{21}$ Maanso poetry is one of the two main divisions of Somali poetry (the other being hees, which includes most of all working songs, children songs and other songs performed while doing something else, see Orwin 2005 , p. 286). It is a (politically or socially) engaged poetry, alliterative and with a distinct metrical scheme. More interestingly for the aim of this book, it displays:

- A strong concept of authorship (claiming a line as one's own when it is not entails the risk of being ridiculised and attacked, see Orwin 2005, p. 288).

- A strong concept of text as a definitive entity (in principle, no additions or deletions - not even by the author, it seems - are admitted, although human memory is frail and occasional alterations have been observed, see Orwin 2005, pp. 287-288).

How did writing (Somali has first been written in an official script in 1972, but "a number of people, both Somalis and non-Somalis, had used writing prior to this time", Orwin 2005, p. 293) affect this reality? Hardly at all, explains Orwin.

Poets have kept on composing and performing definitive texts as before. Listeners have kept on thinking of definitive texts in the same way. Thus, the concept of strong authorship and of definitive text is:

- Not an exclusively Western concept ("I wish to show that I am not dealing with a conception based on the written word and imposed upon the material by a Western academic but with a concept intrinsic to the Somali conception of maanso", Orwin 2005, p. 279).

- Not linked with writing (Orwin quotes Said Sheikh Samatar speaking of "an unwritten copyright law, no less strict than those observed in literary societies", Said 1982, p. 64)

- Not incompatible with the oral performance of poetical texts.

\footnotetext{
${ }^{20}$ Colas accordingly states that "orality is of multiple types" ("l'oralité est multiple"), distinguishing Vedic orality - comparable to a mental writing-from epic orality, which favors interpolations and transformations (Colas 2012, p. 30).

21 I am grateful to Giorgio Banti who made me aware of the case of Somali poetry and gave me a copy of Orwin's article.
} 
In sum, writing does not automatically fix a text, just like performing it orally does not imply that the text is an open one. As shown above, the definitive aspect of a written form has not always and everywhere been felt as such.

However, writing may interfere with the literality of quotations, though only indirectly, insofar as: (1) cursive kinds of writing and print allow a wider circulation of the text to non-insiders, and, hence, a control by the audience; (2) writing allows only a limited space to glosses, interpolations and addenda (adding an extra folio is not always possible and is anyway more expensive than adding a few strophes in a poem one knows by heart); (3) writing means reflecting on what belongs to the text and what does not, and may have influenced the processes of fixation of "Canons". ${ }^{22}$

\subsection{Implicit auctoritas or Explicit auctoritates?}

Quoting, extensively quoting from an earlier text may mean that one is aware that everything worth saying has already been said. This is consistent with the Indian idea of cyclical time or of a time without beginning. In both cases, all possibilities have already been considered. One can only add new forms to well-established contents, as proposed by Bhața Jayanta in the prologue of his Nyāyamañjari (reproduced and discussed in Graheli's contribution, section 4), by Abhinavagupta at the beginning of his Abhinavabhāratī (see Graheli 2008) or by Veñkațanātha (also known as Vedānta Deśika) in the mañgala of his Yādavābhyudayakāvya.

Better, this habit may become itself part of the intellectual étiquette. Authors such as Jayanta do much more than they avow and many thinkers conceal innovations in old forms. In the West, one is led to think of Aquinas, who has been (rightly) accused of "innovation" in his interpretation of some Aristotelian loci, but who refrains from saying where in the Summa Theologica he is expressing his own opinion. Similarly, Patañjali's Mahābhāşya is often still enigmatic for today's researchers, since it is hard to distinguish between Patañjali's own ideas and what he brings in from previous thinkers.

More generally, in India, just like in the Western Middle Ages, claiming to say something new would have diminished the authority of one's statements. As stated by Karin Preisendanz,

[I]nnovation proceeded in the guise of elucidation-understood as interpretation in the broadest sense - and of defense, within an intellectual community which would probably not have sanctioned immediate modification of the teachings of basic works within one's own respective tradition, not to mention outright challenge or even dismissal of them with subsequent innovation. [...] This explains why, in general, no express claim is made to intellectual originality or innovation on the part of individual classical and medieval thinkers: before the early modern period it is rather explicitly denied by some (Preisendanz 2008, pp. 606, 607-608).

\footnotetext{
22 It might be interesting to note that this is a post hoc process. Writing and even more printing do not in themselves cause a standardisation of orthography, canons, etc., but they allow a greater circulation of texts and enable their comparison. This, in turn, may prompt people to initiate a standardisation process.
} 
One encounters authors proud of their individual contribution only after the First Millennium AD, and their number increases after the 15th century. Lawrence McCrea has, for instance, dedicated many insightful pages to the attitude of precolonial Mīmāṃsakas who overtly challenged their school's theses (see McCrea 2002 and 2008).

Before that, and side by side with that, the implicit assumption reigned that authority had to do with the auctoritas, and, consequently, with the auctores one was quoting from.

In order to add authority to one's text, hence, one needed to quote from authoritative works. Did one also need to name the authorities one was quoting from? Yes, insofar as the author's name (or reference to his/her name) stressed his or her authority. However, in cases of very well known authors and texts, such as the Bible or Peter Lombard's Sentences, the reference could also be quite causal and imprecise. The audience would have been able to collocate the quote immediately.

The answer is even more ambiguous in the Indian sāstric tradition. In fact, one notices cases where an authority is explicitly named in order to add authority to one's text. For instance, Madhva used quotes from specific Sacred Texts, often unknown ones-or perhaps even made-up ones ${ }^{23}$ - in order to confirm his most innovative conclusions.

On the other hand, within a philosophical school, borrowing from one's predecessors was licit and one did not care about naming one's source (see Trikha 2012, and Freschi's and Graheli's contributions to the present volume). This might be due to the fact that the individual author felt himself as part of the tradition and hence, as its legitimate heir, could use everything belonging to it. Else, it is also possible that the audience immediately recognised such implicit quotes of former, authoritative texts, once embedded in a later text. It is worth remembering, in this context, that listeners and readers in classical India were limited to the cultured élite. Authors did not need to address the requirements of a lay reader. Moreover, many important texts of one's school or of general significance were learnt by heart and, thus, many quotations were easily recognised by competent readers/listeners. ${ }^{24}$

I dare not say that every single quote could be identified and correctly attributed to its author, rather that the listener could at least recognise it as part of the school's lore and, hence, as authoritative and correct.

The situation dramatically changed in India only with the advent of print, which allows uncontrolled distribution to all sorts of readers. ${ }^{25}$ Similarly, it is not until the 16th c. that a relatively uniform typographical way to mark quotations started to

\footnotetext{
23 On this controversy, see the data collected in Mesquita 2000 and Mesquita 2008 and the overview of the literature against or in favour of Mesquita's thesis in Okita 2011. See also infra, section 4.4.

${ }^{24}$ I thank Evgeniya Desnitskaya for having discussed this point with me. Desnitskaya maintains that: "However, with the course of time, this way of dealing with quotations became untypical. Later on, quotations in texts were usually attributed. This could be due to the decline of mnemonic techniques as well as to the fact that the texts became more and more complicated and thus it was impossible to memorize them" (on this last point, see infra, section 5). The increasing number of non-memorized texts is indeed very much a factor to be taken into account.

25 I am grateful to Chakravarthi Ram-Prasad for having discussed this point with me.
} 
evolve in the West, ${ }^{26}$ and even today double quotes are still ambiguous, since they are used not only for quotations, and since they may mark not only verbatim but also ad sensum quotations (notably, in newspapers). ${ }^{27}$

\subsection{Sacrum Furtum or Plagiarism?}

In order for a theft to be one, the thief needs to know s/he is taking something which does not belong to him/her. Even in the case of intellectual theft, the problem remains: did Indian and Western post-classical and pre-modern authors know they were "stealing" someone other's ideas?

On the one hand, much points to the conclusion that no theft was meant to be carried out (hence, no "theft" occurred-apart from what we consider to be theft). Ancient and Medieval authors used their predecessors' works as if they were their own. Previous texts and sentences were raw, reusable, materials like the old pillars used in order to build a new church. No one felt a precise interruption within the living tradition starting with the sütras and going on until one's own lifetime. Hence, these authors may be accused of a lack of appreciation of the historical depth, not of plagiarism.

On the other hand, as already hinted at in section 4.3, the situation changes slowly and unevenly from the first centuries of the Second Millennium AD onwards. Preisendanz (2005), McCrea (2008) and other researchers in the Sanskrit Knowledge Systems group enquiring on pre-colonial Sanskrit texts have, for instance, shown an increasing appreciation of historical depth and distance from the foundational texts of one's school. A similar, significant evidence of a shift of attitude is that of the Madhva-Venkațanātha polemics (discussed in Mesquita 2000, see also fn. 23). Someone, perhaps Madhva, has been censured by Veñkatanātha because of faking authorities. If this accusation is true, then one could say that his recipient did not feel close enough to the texts as to be allowed to interpret them freely, and rather felt the need to forge new ones. If it does not hold, it nonetheless shows that forgery was felt as a major offence.

\footnotetext{
26 On the history and evolution of quotation marks, see the illuminating and rich Finnegan (2011, chap. 4). Finnegan starts by comparing samples (in books dated between 1526 and 1885) of the same Biblical passage and noting that "the striking thing is that in earlier years neither the inverted commas of contemporary English-language texts nor their more angular continental equivalents apparently played their now-familiar role in marking quotation. Whether in the manuscript tradition of Christian and preChristian authors or in early printed books, quotation marks in the form we know them now were absent" (Finnegan 2011, p. 86). Finnegan then identifies the origin of the idea of typographically marking quotations in the diple, a "graphic sign used by Greek editors to draw attention to something noteworthy in the text", found already in "early Greek manuscripts" (Finnegan 2011, p. 86) (unfortunately, no date is given, but the mention of papyri and the hint at the fact that a development took place "in the second century BC" means that the evidence of this graphic sign can go back to the IV-III century BC). My attention has been driven to Finnegan by the well-documented Theophanidis (2012), which includes beautiful images of 16 th century usages of quotation marks and lists further relevant literature.

27 On the multiple usages of quotations, see Finnegan (2011, chap. 4.2), for the history of what quotation marks should do, and Finnegan (2011, pp. 43-55), where inconsistencies in written samples and in selfdescriptions of one's usage are discussed. More in general, Finnegan notes that "The concept of 'exactness' is in any case a relative one, working differently in different settings", so that in such different settings the same sentence will or will not be put within quotation marks (Finnegan 2011, p. 103).
} 
The Buddhist case might seem more limited by the fact that Buddhism had a historical founder and, hence, a Canon. Nonetheless, this Canon grew up and changed century after century, so much that there are several Canons quite different from each other, and several Buddhist schools disagreed as for its composition, thus generating discussions which throw interesting light on the way their authors felt about open and closed texts. ${ }^{28}$

\subsection{Reuse and Originality}

Apart from the points already mentioned, the amount of textual reuse may also be a useful device to understand an author's compositional habits and his/her "originality". This concept is in bad need for a definition within Indian standards. In fact, Indian authors may rather be flawed because of plagiarism and are all by and large non-original. Contemporary scholars often look for monographs within Indian śāstra literature in vain, and find commentaries and commentaries on commentaries instead, or at most half-commentaries (such as Jayanta's Nyāyamañjarī, which comments only on a selection of Nyāyasütras).

But, looking at the way one builds texts through quotations and departing from quotations, one eventually understands that an Indian author's skill (and "originality") can be recognised indeed in his/her apt arrangement of them. Similarly, I. Tieken-Boon van Ostade writes about Lindley Murray's Grammar:

Despite the taint of plagiarism which his working method undeniably has, Murray nevertheless deserves credit for a certain amount of originality in his work. Among other things [...] this originality lies in the way in which he handled his sources, producing a better product as a result (Tieken-Boon van Ostade 1996, p. 91).

I shall argue in my own contribution (Freschi, infra) that this is the case in Rāmānujācārya's Tantrarahasya, which is sometimes slightly more than a patchwork of former quotations. Still, Rāmānujācārya manages to collect quotations on the same theme from different works, to put them face to face and to make them, in some selected cases, crash. Similarly, Himal Trikha notes how Vidyānandin reuses several passages (ranging from acknowledged quotations to loose references) but the structure of the text is his and independent of them. They are-in Trikha's terminology-Bausteine (building blocks) of his text. This is also proved by the fact that arguments are not quoted en bloc, but rather piecemeal (Trikha 2012, p. 150).

Discussing the case of "creative" commentaries, K. Preisendanz makes a similar point:

[B]ecause of the dominant cultural concept of the timeless authority of foundational works, philosophers felt obliged to present new materials in the

\footnotetext{
${ }^{28}$ For a short introduction to the problem of canonisation in Buddhism, see Lancaster (2005). More specific studies are Mizuno (1982) (which I could not access) and Collins (1990). The latter discusses the concept of open and closed canon (thus showing that "Canon" does not imply closedness) and then the evolution and historicity of one of this canons, the Pāli one, which is often regarded as the earliest one (by contemporary scholars) or as the original one (by Theravādins).
} 
form of commentaries, but could at the same time use the authority of the basic text as a vehicle for the establishment of their own ideas or even their own innovative tradition. Radhakrishnan speaks of "conservative liberalism", in the form of importation of the new into the old [...]. Strauss (1925, p. 229) draws attention to the extreme case of the commentaries on the Brahmasutra by Śankkara and Rāmānuja, Nimbārka and Vallabha, which introduce a new tradition in the guise of a commentary (Preisendanz 2008, p. 608).

Unluckily enough, most Indian authors do not write a "foreword" to their works, explaining how they started working on them. But one might imagine something like the process described by Layamon, a Middle English author writing about 1200. In his prologue, he says that "he took three books, laid them out before him, and turned their pages. Then:

He took feathers in his fingers and applied them to book-skin and set down together the truer words and compressed those three books into one. ${ }^{29}$

Last, I would like to point to the fact that reusing a textual material implies repeating it in a new context and, thus, opening both the reused text and the new context to new potentialities. The dialectic of conservatism and innovation thus implied in each instance of textual reuse can have surprisingly original results and open completely new perspectives, like for instance in Derrida's deconstruction. The fact that contemporary authors and scholars have been intellectually influenced by the Romantic myth of the genius should not make us forget the "creative potential" of textual reuse:

Citation conjures something new into the world by deconstructing the intelligibility and legibility of the social forms that it reanimates, introducing an alterity through repetition. [...] [T] he citation is always not quite. And by being not quite, the citation provides an opening to new possibilities for being in the world (Nakassis 2013, pp. 71, 76).

\subsubsection{Use, Misuse and Peruse of Texts}

Now, I shall contemplate an idea, namely, that - against general expectationstextual reuse often tells us more than an "original" text about the intention of its author (see De Simini, end of the first section).

If someone has something to say, s/he will probably just say it. Why does s/he, instead of it or on top of that, reuse someone else's text?

(1) In order to add authority to his/her statement (since X said it, it must be true) (see Freschi, Hugon, Kieffer-Pülz, Vergiani).

(2) In order to elaborate on a preceding and well-known text:

- Because $X$ has already said something very significant on that subject and one finds it convenient to just reuse the same text (see Freschi, Graheli,

\footnotetext{
${ }^{29}$ Fethereh he nom mid fingren, ond fiede on boc-felle, / Ond tha sothere word sette to-gadere, / Ond tha thre boc thrumde to are (Brut, Caligula version, 26-28). The whole passage is quoted in Burrow (1982, p. 29).
} 
Hugon, Kieffer-Pülz). The reused text might be chosen because it is the standard one in one's school and/or because it can be easily memorised, it is compact and well-written.

- Because $X$ has already said something very significant on that subject and one cannot ignore it (see Kieffer-Pülz, Ruiz-Falqués).

- Because X has already said something very significant on that subject and one wants to silently improve on it.

(3) In order to present an objection (see Freschi, Graheli, Hugon).

Examples of the first case are quite common; within the present volume, one is lead to think at the use of Dharmakīrti's name and words among Tibetan epistemologists (see Hugon, section II.1.A.a). The situation described in the first sub-type of the second case occurs frequently with the texts of one's own school (see below, section 5). The second sub-type of the second case is possibly the one of previous grammarians whose views one does not share, but which one cannot but refer to (see Ruiz-Falqués' article and especially its conclusions).

The third sub-type of the second case might also be very promising. If an author quotes a passage and then interprets it in a forced way, this might mean that s/he had to quote it (for instance, because it was the standard text on that particular theme), and hence needed to force its interpretation into his/her own in order to legitimate it (on this topic see Vergiani's contribution, especially section 3, and Dębicka-Borek's contribution).

An instance from the school I am more familiar with, i.e., Mīmāṃsā:

Śabara opens his discussion on the principles of tantra and prasanga with a verse which-he says-is used as an illustration (udāhr-). The verse is immediately followed by Śabara's own reading of it, by a metaphorical illustration and by a short definition by Śabara himself. It is interesting to observe that neither the verse nor the metaphorical illustrations fit comfortably in Śabara's own definition of prasanga (as shown in Freschi and Pontillo 2013). Bronkhorst (1986) went so far as to state that Śabara's interpretation of the verse misconstrues it. ${ }^{30}$ But why did he, then, use the verse and the metaphors? I think that Sabara had to mention the verse and the metaphors, because they were already well-known and each student would have immediately thought of them. However, Śabara then domesticates them into his own view. In this way, he conveys the idea that his innovation was already common sense among Mīmāṃsakas.

\section{Some Preliminary Results}

During the research which led to the following studies, the other authors and I have noticed that some elements are not indicative:

\footnotetext{
30 "It is not clear why Śabara misinterpreted the verse the way he did [...] One gets the impression that Śabara himself was not very clear about the precise meaning he wanted to assign to the two terms" (Bronkhorst 1986, p. 80).
} 
- $\bar{a} h$ - and similar verbs do not necessarily introduce a literal quotation ${ }^{31}$

- iti can be used to indicate the end of a quoted passage, but also at the end of a direct speech, of an objection or of an argument

- 'vacana can be used for both one's authorities and one's opponents (as explained by Himal Trikha during the workshop organised by the present research-project, see above, section 2, and then in Trikha forthcoming)

- literality is not the norm; although literal quotations might seem to weigh more (see on this regard fn. 49 in Hugon's II.1.A.a; De Simini, section 3, and Graheli), they are by no means the rule, even when one wants to add authority to one's statements

Notwithstanding that, as a general tendency, just as we can say that ucyate by rule introduces a siddhānta, similarly,

- In the majority of cases, authors or texts, if at all identified, are identified with epithets (vārttikakāra, bhāșyakāra...) (see Freschi, Graheli, Kieffer-Pülz)

- Quotations of sütras and metrical passages tend to be closer to the original than quotations of non-metrical texts, this is even more so in the case of Pānini's Asțāahyāȳi (see Freschi, Graheli, Hugon, Pellegrini, Vergiani)

- tad uktam, uktam hi, uktam ca, ity uktam and similar formulas tend to be used to introduce acknowledged textual reuse; moreover they often introduce literal quotations (see Andrijanić, Graheli, Kieffer-Pülz, Ruiz-Falqués, Vergiani)

- Acknowledging textual reuse, especially by naming the author, can be used by authors in order to add authority to a statement (see Hugon), and, thus, while taking a difficult move or while explaining a position which is not obviously shared by the members of one's own school (cf. also Mesquita 2000 concerning when and why Madhva introduced a quotation)

- However, mentioning the name of one's source may also mean that the author is distancing himself from it and considers it not part of his own school (see Freschi); such instances may be easily identified by the presence of adverbs such as pana (Skt punah) (see Kieffer-Pülz, Ruiz-Falqués) ${ }^{32}$

- Postclassical authors tend to acknowledge textual reuse and to name their sources more often than their forerunners (see Andrijanić, Doctor, Kieffer-Pülz)

- Connected with the above point: the competence of the readership/audience of a text influences the style of reuse

\footnotetext{
31 Steinkellner discusses how he had to restrict the scope of $\mathrm{Ce} / \mathrm{Re}$, in the case of nonextant texts, to a purely formal distinction "in consideration of, e.g., the following circumstances. On the one hand, the occurrence of $\bar{a} h a$ introducing what is only a summarising report of a passage in Pakșilasvāmin's Nyāyabhāşya (PST 1.99,12-16) does not allow us to generalise the definition of Ce introduced above in the sense that all such passages would have to consist of more $(\mathbf{C e})$ or less (Cee) literal citations" (Steinkellner et al. 2005, p. liv).

32 Some sort of intermediate position is analysed by Graheli, who notes that Jayanta may reuse without any acknowledgement the Nyāyabhāṣya (a text of his own school), while he names adversaries with whom he agrees (Śabara and Kumārila) and does not name at all adversaries with whom he overtly dissents (Bharțhari).
} 
- Unacknowledged textual reuse ("repeats" in Hugon's terminology) are the rule within the textual material of one's own school and rather exceptional outside of it (see De Simini, Freschi, Graheli, Hugon, Kieffer-Pülz)

Kieffer-Pülz' article in this volume includes interesting conclusions about the marks of reuse in Pāli texts. In fact, Kieffer-Pülz' article lays down for Pāli what I would have liked to achieve for Sanskrit with the present volume. The Sanskrit landscape has proven itself too heterogeneous to make such an overview possible, but it is to be hoped that further studies will integrate these short notes.

\section{Some Further Explanations on this Volume’s Essays}

The general focus of this volume is on the study of textual reuse in philosophical texts. During my first call for papers, I have especially highlighted the need for a technical analysis of data, with case studies of the usage of verba dicendi etc., within philosophical texts. This kind of concern is particularly evident in Doctor, Freschi, Graheli, Hugon, Kieffer-Pülz, Neri, Ruiz-Falqués and Vergiani, whose relevance for the topic of this volume will, thus, be immediately clear. A few more words might be necessary for some of the other articles.

In fact, while working on the topic of textual reuse I have also felt the need to open up the topic in order to gain further insight into the wider Indian background and to compare it with the specific case of philosophical texts.

In this sense, Elena Mucciarelli's paper focusses on the early history of textual reuse in the Vedic Saṃhitās. It is, therefore, even more interesting to recognise patterns of reuse (e.g., modified textual units as a result of their adaptation to a new context) which are observed also in later contexts.

Ewa Dębicka-Borek's paper is an interesting example of how telling the reuse of a text may be. In fact, after analysing the general habit of textual reuse in the Pāñcarātra tradition, it discusses in detail a seeming exception, i.e. the Narasiṃhadīkșā. An (oral or written) text describing it had been introduced in the Sātvata Saṃhitā, where the compiler of the Saṃhitā clearly tried to make the text look more "orthodox" by introducing it as a subsidiary to the initiation rite. The later compiler of the İśvara Saṃhitā, though reusing most of the Sātvata Saṃhitā material, omits the Narasiṃhadīkșā, possibly because he thought that its heterogeneity could not be suitably concealed, not even through a proper context. Thus, the choices made while reusing are an interesting key to understanding the motivations of (authors and) compilers.

Florinda De Simini's paper nicely shows how reusing can be an authorial activity through the case of the Dharmanibandhas, which are often no more than jigsaws of quotations, but where it is exactly the choice of the authorities to be quoted which is highly informative. 
Cristina Bignami's paper, shows how the categories discussed in this introduction can be used also in the field of art history, thus opening a promising field for further investigations. $^{33}$

Moreover, although most papers focus on the analysis of textual reuse as a powerful tool for reconstructing the intellectual history of Indian thought, some of them focus also on its applications. Ivan Andrijanić' essay shows how a careful study of the approach to reused passages can be helpful in recovering a text preserved only in fragments.

Krishna Del Toso's contribution shows how the analysis of the quoted materials, of their position in the text and of their sequence may help us reconstruct the history of a text.

Malhar Kulkarni's paper analyses some quotations of Pānini in the Káśika Vrtti and discusses their variations compared to the transmitted wording of Pānini's Asțāahyāy $\bar{l}$, thus showing how the historical study of textual reuse can fruitfully interact with manuscript analysis.

Gianni Pellegrini's paper aims at reconstructing the intellectual landscape of NorthEast India in the 16th c. through the texts reused by one of its protagonists, Madhusūdana Sārasvatī. On a similar level but with the additional feature of dealing with two worlds at once (i.e., Sanskrit texts and their Tibetan renderings), Ulrike Roesler's paper shows how the study of textual reuse may help to reconstruct the history of the library of an author, thus revealing features no longer present in the later canonised versions of such libraries. Also Pascale Hugon's study leads to interesting conclusions about the reading habits of the scholars of epistemology up to Sa skya Pandita in Tibet, thus showing how the focus on a different context (epistemology vs. religion) can lead to partly overlapping and partly divergent results.

As for the geographic and cultural focus of the volume, I have been immensely pleased to be able to discuss South Asia and not only Sanskrit India. Hugon and Kieffer-Pülz have provided some background information on the Tibetan and Pāli contexts respectively. Within the latter, Kieffer-Pülz', Neri's and Ruiz-Falqués' articles discuss a similar period and in this sense the three Pāli articles constitute a small monographical work within the larger frame of this book, whereas the articles dealing with Tibetan material (Del Toso's, Hugon's, Roesler's) highlight different aspects of the Tibetan culture and of its relations to Sanskrit models.

Sakai's article is the only one focusing on a peculiar kind of reuse, i.e., self-reuse. In fact, it analyses Dharmottara's reuse of his own arguments from one work to the other. This analysis contributes, on the one hand, to our understanding of the intellectual background of such authors (which audience did one write for? when was one allowed to write commentaries?, etc.) and on the other to the kind of editing at stake in each instance of reuse. The fact that Dharmottara could reuse freely his own work may, thus, indirectly point to the general possibility of freely reusing materials one agreed with. Last, Sakai's study paves the way to an inquiry into reuse and originality (hinted at above, section 4.5), which has been the topic of a panel at the 32nd Deutscher Orientalisten Tag (Münster, September 2013) and will be the topic of a separate volume (edited by me together with Philipp Maas, Freschi and Maas forthcoming a).

\footnotetext{
33 As a supplement to this statement, I am pleased to add that Cristina Bignami, Julia Hegewald and myself will host a panel on reuse in the arts at the next EAAA conference, to take place in September 2014.
} 
Acknowledgments I started conceiving this study in 2009 during my time in Austria with a scholarship of the University of Milan and have been working on it with the help of funds from the University "Sapienza" in Rome and the FWF (as project leader of the Lise Meitner Project M 1437). In chronological order, I am happy to say that I am grateful to Karin Preisendanz, with whom I discussed the case of parallels in the Sānkhya commentaries and the idea of using different shades of grey (see infra, Freschi), to Himal Trikha, with whom I discussed the formal aspect of the representation of textual reuse throughout the last five years, to Ernst Steinkellner for some intriguing discussions on our different approaches, to the participants of the Coffee Break Meeting on "Quotations and Re-Use in Sanskrit Śāstras" held in Rome $2012,{ }^{34}$ and to those who could not make it to Rome but contributed to this volume. Since the topic of textual reuse has become a sort of earworm for me, I discussed it with many colleagues of different fields, whose generous suggestions I acknowledged in the footnotes of this essay. I am further indebted to Shanti Graheli for valuable suggestions on the Western Middle Age case and to Petra Kieffer-Pülz for her accurate reading. I am also grateful to Erika Wieder for a final glance on all the articles. Parts of the sections 3 and 4 had been already published within Freschi 2012. Last, my deepest thanks go to my husband Alessandro for his continuous intellectual challenges and his deeper, unspoken support. This volume, for my part, is dedicated to him.

Open Access This article is distributed under the terms of the Creative Commons Attribution License which permits any use, distribution, and reproduction in any medium, provided the original author(s) and the source are credited.

\section{Appendix}

See Fig. 1.

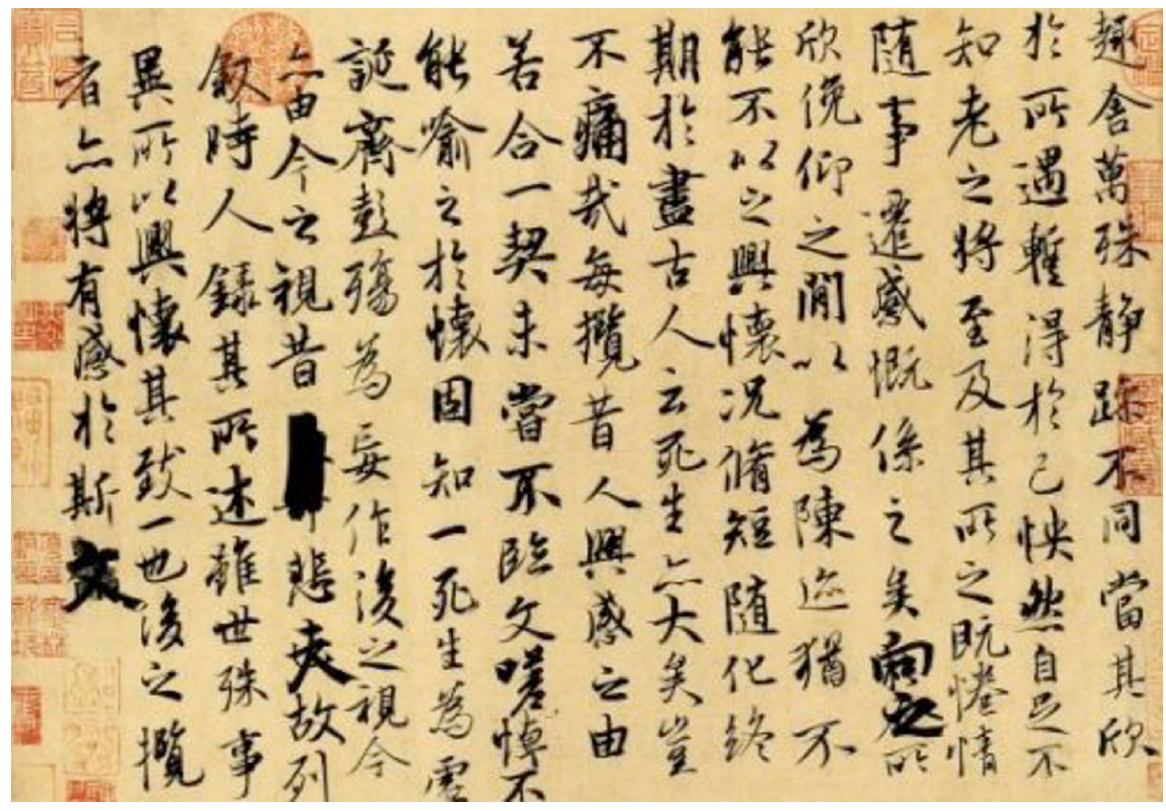

Fig. 1 A section of a Lanting Xu manuscript

\footnotetext{
34 The program and the abstracts of the meeting can be found here: http://asiatica.wikispaces.com/ quotations + and + re-use+of+texts+in+Sanskrit+texts.
} 


\section{References}

In accordance with the theme of this article, I quoted from many studies. Due to the lack of specific studies about the extent of the phenomenon in India, I relied also on materials about the Western scenario, which had the benefit of stressing unexpected similarities and dissimilarities.

Bartels, H. (2009). Die Piratenpartei. Entstehung, Forderungen und Perspektiven der Bewegung. Reihe Netzbürger 1. Berlin: Contumax.

Berti, M. (2013). Collecting quotations by topic: degrees of preservation and transtextual relations among genres. Ancient Society, 4, 269-288.

Bronkhorst, J. (1986). tantra and prasanga. Aligarh Journal of Oriental Studies, III(2), 77-80.

Büchler, M., Geßner, A., Berti, M., \& Eckart, T. (2013). Measuring the influence of a work by text re-use. In S. Dunn \& S. Mahony (Eds.), The digital classicist. Bulletin of the Institute of Classical Studies Supplement 122 (pp. 63-79).

Burrow, J. A. (1982). Medieval writers and their work: Middle English Literature 1100-1500. Oxford: Oxford University Press.

Cao, C. (2012). Per una poetica del plagio: il caso di Kathy Acker. Between,II(3), 1-23.

Colas, G. (2012). Histoire, Oralité, Structure. À propos d'un tournant dans l'oeuvre de Madeleine Biardeau. Journal Asiatique,300(1), 17-32.

Collins, S. (1990). On the very idea of the Pali Canon. Journal of the Pāli Text Society, 15, 89-126.

Finnegan, R. (2011). Why do we quote? The culture and history of quotation. Cambridge: Open Book Publishers.

Freschi, E. (2012). Proposals for the study of quotations in Indian philosophical texts. Religions in South Asia, 6(2), 161-189.

Freschi, E., \& Maas, P. A. (Eds.). (forthcoming a). Adaptive reuse of texts, ideas and images in classical india adaptive reuse of texts, ideas and images in classical india adaptive reuse of texts, ideas and images in Classical India. Wiesbaden: Harrassowitz.

Freschi, E., \& Maas, P. A. (Eds.). (forthcoming b). Introduction. In E. Freschi \& P. A. Maas. Adaptive reuse of texts, ideas and images in Classical India. Wiesbaden: Deutsche Morgenländische Gesellschaft. Harrassowitz.

Freschi, E. \& Pontillo, T. (2013). Rule-extension Strategies in Ancient India: Śrautasūtra, Mīmāmsā and Grammar on tantra- and prasanga-principles. Frankfurt am Main: Peter Lang.

Graheli, A. (2008). In praise of repetition. IIAS Newsletter, 48, 24.

Hegewald, J. A. B. \& Mitra, S. K. (Eds.). (2012). Re-use: the art and politics of integration and anxiety. New Delhi and Thousand Oaks, Calif: SAGE.

Kellner, B. (2007). Jñānaśrimitra’s Anupalabdhirahasya and Sarvaśabdābhāvacarcā: A critical edition with a survey of his Anupalabdhi-theory. Wiener Studien zur Tibetologie und Buddhismuskunde 67. Wien: Arbeitskreis für Tibetische und Buddhistische Studien, Universität Wien.

LaFollette, M.C. (1992). Stealing into print: Fraud, plagiarism and misconduct in scientific publishing. Berkeley: University of California Press.

Lancaster, L. R. (2005). Buddhist books and texts: canon and canonization. In L. Jones (Ed.), Encyclopedia of religion (pp. 1251-1258). Detroit: Macmillan Reference USA, Thomson Gale.

Lasic, H. (Ed.). (2000a). Ratnakīrtis Vyāptinirnaya, Sanskrittext, Übersetzung, Analyse. Wiener Studien zur Tibetologie und Buddhismuskunde 49. Wien: Arbeitskreis für Tibetische und Buddhistische Studien, Universität Wien.

Lasic, H. (Ed.). (2000b). Jñānaśrimitras Vyāpticarcā. Sanskrittexts, Übersetzung, Analyse. Wiener Studien zur Tibetologie und Buddhismuskunde 48. Wien: Arbeitskreis für Tibetische und Buddhistische Studien, Universität Wien.

Mac Allister, P. (2011). Ratnakīrtis Apohasiddhi. A Critical Edition, Annotated Translation, and Study. PhD thesis. Wien: Universität Wien.

McCrea, L. (2002). Novelty of Form and Novelty of Substance in Seventeenth Century Mīmāmsāa. Journal of Indian Philosophy, 30(5), 481-494.

McCrea, L. (2008). Playing with the system: Fragmentation and individualization in late Pre-colonial Mīmāṃsā. Journal of Indian Philosophy, 36(5-6), 575-585.

Mesquita, R. (2000). Madhva's unknown literary sources: Some observations. Delhi: Aditya Prakashan.

Mesquita, R. (2008). Madhva's quotes from the Purānas and the Mahābhārata: An analytical compilation of untraceable source-quotations in Madhva's works along with footnotes. Delhi: Aditya Prakashan. 
Mizuno, K. (1982). Buddhist Sūtras: Origin, development, transmission. Tokyo: Kosei.

Mülke, M. (2008). Der Autor und sein Text: die Verfälschung des Originals im Urteil antiker Autoren. Berlin: Walter de Gruyter.

Nakassis, C. V. (2013). Citation and citationality. Signs and Society, 1(1), 51-78.

Nikolsky, R. (2010). Ishmael sacrificed grasshoppers. In M. Goodman, G. H. van Kooten, \& J. T. A. G. M. van Ruiten (Eds.), Abraham, the nations, and the Hagarites: Jewish, Christian, and Islamic perspective on kinship with Abraham (pp. 243-262). Leiden and Boston: Brill

Okita, K. (2011). Review of Roque Mesquita, Madhva's Quotes from the Purāṇas and the Mahābhārata: An analytical compilation of untraceable source-quotations in Madhva's works along with footnotes. Indo-Iranian Journal,54, 185-192.

Orwin, M. (2005). On the concept of "definitive text" in Somali poetry. Oral Tradition, 20(2), 278-299.

Preisendanz, K. (2005). The production of philosophical literature in South Asia during the pre-colonial period (15th to 18th centuries): The case of the Nyāyasütra commentarial tradition. Journal of Indian Philosophy,33, 55-94.

Preisendanz, K. (2008). Text, commentary, annotation: Some reflections on the philosophical genre. Journal of Indian Philosophy, 36, 599-618.

Said, S. S. (1982). Oral poetry and Somali nationalism: The case of Sayyid Mahammad 'Abdille Hasan. Cambridge: Cambridge University Press.

Schulze, C. (2004). Das Phänomen der "Nichtkommentierung" bedeutender Werke. In W. Geerlings \& C. Schulze (Eds.), Der Kommentar in Antike und Mittelalter Bd.2 Neue Beiträge zu seiner Erforschung (pp. 21-33). Clavis Commentariorum Antiquitatis et Medii Aevi. Leiden: Brill.

Steinkellner, E. (1988). Methodological remarks on the constitution of Sanskrit texts from the Buddhist Pramāna-tradition. Wiener Zeitschrift für die Kunde Südasiens, 32, 103-129.

Steinkellner, E., Krasser, H., \& Lasic, H. (Eds.). (2005). Jinendrabuddhi's Pramāṇasamuccayațīkā. Chapter 1, Part 1: Critical Edition. Part 2: Diplomatic Edition. Wien, Beijing: Österreichische Akademie der Wissenschaften, China Tibetology Publishing House.

Strauss, O. (1925). Indische Philosophie. In G. Kafka (Ed.), Geschichte der Philosophie in Einzeldarstellungen. München: Ernst Reinhardt.

Theophanidis, P. (2012). The origin and development of the quotation mark. http://aphelis.net/origindevelopment-quotation-mark/.

Tieken-Boon van Ostade, I. (1996). Lindley Murray and the concept of plagiarism. In I. Tieken-Boon van Ostade (Ed.), Two hundred years of Lindley Murray (pp. 81-96). Münster: Nodus Publikationen.

Trikha, H. (2012). Perspektivismus und Kritik. Der epistemische Pluralismus der Jainas angesichts der Polemik gegen das Vaiśeșika in Vidyānandins Satyaśāsanaparīkșā. De Nobili Research Library 36. Wien: De Nobili.

Trikha, H. (forthcoming). Facets of a fragment: Evaluation and classification of intertextual elements in a philosophical Jaina Sanskrit work. In E. Prets \& H. Marui (Eds.), Transmission and reflection. The meaning and the role of 'fragments' in Indian philosophy. Proceedings of a symposium on quotations and paraphrases from and allusions to ancient texts on Indian philosophy. Wien: Österreichische Akademie der Wissenschaften.

Tubb, G., \& Boose, E. R. (2007). Scholastic Sanskrit. Treasury of the Indic Science Series. New York: AIBS.

Wezler, A., \& Motegi, S. (Eds.). (1998). Yuktidīpikā: The most significant commentary on the Sāmkhyakārikā. Stuttgart: F. Steiner. 